\title{
A Preliminary Sketch of the History of Child Study, for the Year Ending September, 1896
}

\section{Sara E. Wiltse}

To cite this article: Sara E. Wiltse (1896) A Preliminary Sketch of the History of Child Study, for the Year Ending September, 1896, The Pedagogical Seminary, 4:1, 111-125, DOI: 10.1080/08919402.1896.10532958

To link to this article: http://dx.doi.org/10.1080/08919402.1896.10532958

册 Published online: 28 Aug 2012.

Submit your article to this journal $₫$

Џ Article views: 3

Q View related articles $\widetilde{ }$

Citing articles: 1 View citing articles 


\section{A PRELIMINARY SKETCH OF THE HISTORY OF CHILD STUDY, FOR THE YEAR ENDING SEPTEMBER, 1896.}

By SARA E. WILTsR.

In continuing the preliminary sketch of the external history of the child study movement since the close of my article ${ }^{2}$ of a year ago, I am beset with many unexpected difficulties. The work has grown so rapidly, and from so many new centers that to be exhaustive I should have to fill the space at command with the names of new associations that have been formed, during the year under review, the new articles, workers, methods, etc. Although my sketch is only of the external history and although my duties as secretary of the National Association have expired, I am glad at the request of the editor of the Pedagogical Seminary to undertake to re-edit here two partial papers of mine, one read at the Child Study Section of the N. . A. at Buffalo, and the other at the Summer School at Clark University, both in July, 1896, based upon extensive correspondence with representatives of every section I could reach. My obligations to those who have gathered for me the details upon which nearly everything that follows is based are so numerous that I can only express them here in general terms, although I must mention Professor Reigart, of the Teacher's College, New York, Miss Lillie A. Williams, of the State Normal School, Trenton, N. J., who has been the chief co-worker with Dr. Hall during the year, Miss Millicent W. Shinn, President of the Collegiate Alumnæ Association, Superintendent G. E. Johnson, of Andover, Mass., Professor and Mrs. Earl Barnes, of the Leland Stanford University, Mr. Gilman C. Fisher, of the Barnard Club. Providence, R. I., Mr. Luckey, Mr. Patrick, Mr. Louis Galbreath, Dr. Aikins and Principal E. H. Russell. Last and not least to Dr. G. Stanley Hall and the members of the Pedagogical Department of Clark University, especially Drs. Iukens and Allin, and Messrs. Ellis, Scott, Dawson, Bohannon, Small, Lindley, Shaw, Avery, and Mr. Louis $\mathrm{N}$. Wilson, Clerk of the University.

Beginning, as in my former sketch, with Massachusetts, there is still no organization, but most work centers about President Hall. The returns from the fifteen syllabi mentioned last year have been mostly worked up and formed the basis of a one-hour-a-week course given by Dr. Hall at the University throughout the year; and with those from the syllabi of this year made the foundation of his course at the Summer School in July. With his co-laborers Dr. Hall has issued during the year the following additional syllabi: I, Peculiar and Exceptional Children; II, Moral Defects and Perversions; III, The Beginnings of Reading and Writing; IV, Thoughts and Feelings about Old Age, Disease and Death; V, Moral Education; VI, Studies of School Reading Matter; VII, Comparative Study of Courses of Study in the Various Grades ; VIII, Early Musical Manifestations; IX, Fancy, Imagination, Reverie ; $X$, Tickling, Fun, Wit, Humor, Laughing; XI, Suggestion and Imitation; XII, Religious Experience; XIII, Kindergarten; XIV, Habits, Instincts, etc., in Animals; XV, Number and Mathematics ; XVI, the Only Child in a Family, and a supplementary syllabus on dolls.

I See Pedagogical Seminazy, Vol. III, No. 2. 
The work of sifting the thousands of returns from these syllabi in a way to extract their psychological and pelagogical value, is well under way. Dr. Hall has had during a part of the year, four persons employed upon this work at his expense, besides the work of the students named atove. Reports on nineteen of the syllabi were presented at his lectures at the Clark University Summer School and will be printed in this and later numbers of the Pedagogical Seminary and American Journal of Psychology.

His greatest need is now a paid secretary to conduct the correspondence with nearly a thousand people in all parts of the country $w$ ho desire to answer his syllabi; and with others needing direction for the best method of organizing new centers. Unless a salary of twelve or fifteen hundred dollars is speedily forthcoming, many precions possibilities will be lost, as Dr. Hall has already transcended the limits of his own financial ability in this direction. One man should not longer be permitted to do a work 80 full of usefulness for education at large. His plan, he informs me, is to round up and make a period of this work at the olose of another year.

The Clark Summer School, with Child Study as its most nnique and central feature, was much larger than ever before; its ninety-six lectures in two weeks, with every afternoon devoted to laboratory practice in testing children and in psychological measurements with instruments, initiated the several hundred worker from thirty-two states and territories into details of method in child study. An important step, long desired, was the formal assurance of co-operation with child study by the kindergartners present, on the dey of the school which was devoted to their work. As a result of two conferences in which auch prominent leaders took part as Miss Lucy Wheelock, President of the International Kindergarten Union, Mrs. Putnam, Miss Bryan, Miss Payne, Miss Jennie B. Merrill and Miss Zebring, the following resolutions were adopted withont a dissenting voice. Feeling the imperative duty of having in our work as kindergartners and normal teachers, not only a deep reverence and right understanding of Frobel's philosophy, but recognizing also the present need of a clear view of a true paychology of children, we hereby tender our most sincere thanks to Dr. Hall for offering us an opportunity to co-operate with him in the child study movement through the syllabi and in the conferences of this session of the Clark University Summer School.

"We believe that kindergartners everywhere must realize, if they have not alreedy done so, that scientific child study is not and never has been antagonistic to our vital principles enunciated by Frbbel, the great child student, but we also believe that a better lnowledge of genetic psychology is also necessary to ward off any tendency to formalism in the education of little children, which has ever been one of the greatest dangers of the kindergarten system.

"Therefore, in behalf of the kindergartners and training teachers in attendance here we would again thank the president and faculty of Clark University, as well as these ladies who have done so much to make this session full of usefulness as well as enjoyment."

The kindergarten, which is now represented in this country by a better class of workers than in any other land and is more widely supported by public funds than elsewhere, is fast becoming an important part of our national system of education. It is now the only part that has a philosophy, such as it is, which fits and inspires its representatives, and it is already a burning question whether the primary school years shall leaven it or it give its tone to primary grades. It is the vatural point of application for child study results 80 that the above resolutions mark a very important step. Perhaps it would not 
be unfortunate if the line between the ultra conservative worshippers of Frobbl's letter, and the progressives who represent his spirit, were clearly drawn, for in no part of the educational held are these differences greater, and child study is the best possible touchstone to develop this natural polarity. Without going so far as to say here that the kindergarten in this country will languish or flourish according as it accepts or rejects child study, as some now say, no one can doubt that, if alive to-day, Frobel would have been himself foremost among our students of childhood and more severe than any one has ever thonght of being in condemning those who make his letter the coffin of his apirit. In view of this sitastion it is not impossible that the kindergarten day at the Clark Summer School and its results may mark an epoch of great and growing significance for the future of both Frobelism and child study. For her contribution to this siguificant tendency I think special credit is due to the President of the International Kindergarten Union, Miss Lucy A. Wheelock.

Dr. Chamberlain, an instructor in Clark University, brought out last winter (by Macmillan \& Co.) a large anthropological volume entitled The Child in Folk Thought. It is a book of vast erudition, showing from all sources how children have been regarded and treated among the savage races of the world. It is a work which all students of childhood and indeed all parents should read, and is as suggestive as it is full of information. The author is now at work upon another volume showing how childhood has been regarded in the literature of the world.

The Pedagogical Seminary, in the volume ending Jnne, 1896, has some twenty-two child study papers.

In July, I896, Principal E. H. Russell published the first fruits of his many years of child study in the form of a volume of many hundred typical illustrations of imitation. These are printed without note or comment and classified only by years. It contains a brilliant and suggeative introduction in $\mathrm{Mr}$. Russell's best vein. As the pioneer school in this country, and indeed in the world, to reduce child study to a form both pedagogic for students and valuable for science this volume has peculiar significance and is sure to attract great interest. Each of these illustrations is a psychological nugget and is so numbered that theoretical psychologists of the most opposite 8 chools can cite these instances by number as theologians do proof texts from the Bible. Miss Haskell, who has done the very arduous work of selecting and grouping, deserves great praise. Although this institution has now the misfortune of losing Dr. Bolton, who has done masterly work in co-ordinating its results, the future volumes promised in this series will be looked forward to with great interest. As a year ago, so last summer Principal Russell was the only lecturer on child study at the Summer School of Harvard University, where, despite the indifference of its director and of the philosophical department, a large attendance and great interest was secured. Mr. Russell promises another volume upon Knowledge as Gained Through Association.

The Department of Physical Training at Smith College has issued an Anthropometric table based on measurements taken on entering college and ten months after.

William Townsend Porter, M. D., instructor at the Harvard Medical School, published an article in the Educational Review of February on the Use of Anthropometrical Measurements in Schools.

Miss Calkins, Professor at Wellesley, has well sustained the work in child psychology noted in the first part of this sketch.

Perhaps one of the most important, practical movements resulting from child study, and one of the least known, is that of a Play School 
in Andover conducted by Supt. G. E. Johnson, whose One Thousand Classified Plays and Games, mentioned in the first part of this sketch, was followed by an article in the current number of the Peilagogical Seminary on The Training of Idiots. Supt. Johnson has had a Play School in Andover long enough to satisfy himself that his theory is right. It was not necessary to canvass for pupils; Mr. Johnson simply explained the nature of the school, and said any boy wishing to join the class could do so by calling at his office and filling out a blank. Boys between nine and fourteen years were eligible, and forty boys soon filled this application for admission :

The Andover Play School. Application for Admission. I wish to become a member of the Andover Play School. Name. Age. Residence.

Answer the following questions: I What indoor games do you like to play? 2 Which is your favorite? 3 What toy or other thing have you ever made? 4 Name some other things you like to do besides playing games? 5 Can you run a scroll saw? 6 Or a wood lathe? printing press? 7 Can you load and shoot a gun? 8 What do you think you will be when you are a man?

At the close of the school a checker tournament was enjoyed, the boys choosing sides, wearing colors and having leaders. During the term there were evenings devoted to conundrums, puzzles and spelling matches. Parlor magic was tried and any boy allowed to try the trick when he thought he had guessed how it was done. The boys steadily improved in attention, foresight and judgment. Physical training was not omitted. Egg foot ball, wrestling, boxing, target shooting, etc., were practiced. Mr. Johnson planned for a Child Symphony with jews harps, mouth organs, etc., but the time and strength of one man was not equal to this and the other duties of a Superintendent of Schools. It is expected, however, that some of the charitable organizations of Andover will help next year.

Nothing further has been done in Massachusetts towards organization and Boston is now almost the only city of its size that is doing practically nothing for child study, but with so much individual work accomplished in one year we may be content to remain where we have so conservatively seated ourselves - quite behind our western sisters.

California. It is a matter of great congratulation that we are to have the almost classic work of Professor Earl Barnes, who has just issued the first of ten Studies in Education, to be published monthly. The first pamphlet contains the editor's introduction, setting forth the object and method of his work. All that he has done has been based on such vast numbers of individuals that none of his conclusions have been reversed. They are also unique, in that by his method teachers and superintendents not only do the work but make the established computations, while, best of all, every problem of his is not only scientific but more immediately practical for schools than that of any other worker. Professor Barnes has not only lectured in every county but in almost every town in California and has everywhere a wakened greatest interest, which has been fully sustained. His work in the west also complements that of Dr. Hall in the east, in that the former works from a dominant interest in sociology and the latter more from the biological standpoint. With Miss Schallenberger the children's interests, superstitions, ambitions, etc., are being thoroughly studied, and Professor Barnes's maguificent influence has been widely extended eastward by his Presidency of the Child Study Section of the N. E. A. and by his summer lectures at the University of Chicago. Mrs. Barnes is still his most efficient coadjutor.

The State University of California, under Professor Elmer E. Brown, 
is patiently coutinuing physical tests and giving special atteution to ventilation of school houses. Professor Brown's methorls are slow but well considered and thorough, aiming at the - most fundamental problems. Professor Bailey working there from a more Herbartian standpoint sums up views and pleads for a long continued study of children's instincts and the avoidance of conclusions from isolated facts. Judging from the present attitude of the two great Universities of California to-day it would seem that the final adjustment between the scientific and the pedagogic methods would be reached before we fairly realize that there is a difference between them.

Miss Shinn, who has made a pedagogic tour through the east, has continued observations on her nlece, and her work certainly prourises to rank with that of Preyer, if, indeed, it is not destined to be on the whole the best of all studies of an individual child. She has vigorously and successfully pushed the work of Child Stuny among the Collegiate Alumnz during the year. Although the latter seem reluctant to make returns and, Dr. Hall reports, are easily dismayed at the novelty and complexity involved in new work along lines so different from those of the philosophic work they had in college, when they do make records their quality is sometimes of the very best. Why it so often falls short would be an interesting topic for investigation.

Santa Rosa has published two books of stories edited by the public school children, but the suggestion that these would make good reading for children is very questionable on the principle that children's reach far exceeds their grasp, and that they can understand things that are far better than they can produce. The Santa Rosa Reports show how child study has affected the methods of teaching history, and those of the State Council show the effects of child study on the elementary courses of school work in the most interesting way.

Illinois. Illinois has made history within the last year so rapidly that her doings will remain luminous through the Illinois Handbook which grows in interest and value with every issue, and The Child Study Moutbly even if the historian passes her over with but brief mention. At the meeting of the National Fducational Association Colonel Parker represented the work of the Illinois Society of Child Study, which collects data through its three sections, the Northern, Central and Southern. The society has a committee on propaganda which undertakes to reach every teacher and through the teacher the parents who are the backbone of the round tables. Of these round tables there are nearly twenty in the State, each member of which is given some particular line of investigation. The society bas held three great Congresses, the last in Chicago, having a four days' session beginning May 13, 1896. There was a daily attendance of from five hundred to three thousand teachers and parents. State and city superintendents reported on work undertaken, and six universities were represented besides a number of normal schools. Most of the work reviewed bore directly upon the practical needs of the scliools with valuable suggestions from returns as to the remedy of evils discovered.

Among the opinions most strongly expressed and heartily approved were the following : that children are often almost criminally uisunderstood ; that one of the strongest desires of children, whose individuality is in any way marked, is to be sympathetically known; that all children have a natural right to be appreciated, and that the inisunderstanding of children on the part of adults is lamentable and is beginuing to be inexcusable since the search light of scientific child study shows so conclusively that our mistakes are visited upon the children in dwarfed personalities; that the time has come when children must 
not only be loved as animals love their offspring, but parental love must no longer be blind if it is to be complete and efficient.

Another strongly acceuted note of this congress was the reiterated confession in several of the papers that we have taken too narrow views of child life and school work. One essayist is reported to have said that as teachers and parents we have been blind and deaf, have lacked both knowledge and conmon sense, have taken narrow views of school work because we have taken narrow views of child life. This candid confession of shortcoming on our part is the best of omens for the future.

Another striking and interesting feature of this meeting was the session devoted to the anticipations of child study in Pestalozzi, Fröbel and Herbart.

In an evening address Prof. Dewey made three stages of paidological interest: Ist. the political, when children were educated for a very fixed and clearly defined career in an establiwhed political order; 2nd, the social, asthetic stage of the renaissance, when adults saw in children the lost ideals of their own lives, and loved them not co much for the children's sake as for their own. (This stage has many representatives in art and is still seen in its degeverate form of loving children as puppets); 3rd, the modern scientife study of childhood which doee not lessen but increases interest in personality on the principle that the best study follows the deepest interest. Another note of this significant congress was that child study was very effective as a new method of teaching both pedagogy and psychology. Emphasis was placed upon the importance of the teacher's taking the parent's point of view and the parents reciprocating by taking that of the teacher. Mother clubs, Buch as Miss Marsh has started in Detroit where a hundred parents meet fortnightly at the schoolhonse to discuss food, clothing, home work and discipline, with their bearing upon school life, have resulted in good that has more than local interest, for Superintendent Pettingill reports that this conference of teachers and parents has healed an aggravated case of sectarian animosity in that city. One speaker even regretted that teachers could no longer come into the lives of the families as when they boarded around.

Several normal schools reported that child study had proven a new and raluable bond by which these and other institutions could keep up their connection with graduates. This has been proven by the Collegiate Alumaz in particular. Very striking and perhaps extreme were the views of one speaker who insisted that the teachers' passion for correct grammatical construction often checked the natural flow of a child's thought, and I must add that I believe this school mania for correct speech is directly responsible for many a case of stammering and stuttering. This gentleman went so far as to advocate some frcedom in the use of slang by children and would not condemn a little of what he called legitimate darn language.

A nother speaker argued that child study has very strong tendencies to make women teachers more motherly in the school room and tended. to correct the indescribable and disagreeable mannerism of the school ma'am which some women contract for life. What was said sbout its making all teachers more marriageable instead of unfitting them for home probably has a grain of truth in it.

A prominent clergyman declared that church vestries should be open to kindergartens during the week and that child study, which should be inseparable from all education, was needed to bring $\mathrm{church}$ work, so much of which is unpedagogical, upon a natural and healthful basis. In child study he foresaw germs of reconstruction in Sunday School and other church work. It was claimed by another speaker 
that eye tests, and possibly ear tests, could be made by the teachers themselves instead of by specialists so that the teacher could at least decide when the aurist or occulist should be consulted; such training being in the power of any one who would devote a few hours to it. This one result of child otudy, if acted upon, would save not only the eyes but the brain power of many a child who would otherwise become direct charge to the public. An artist defended the thesis that children had inspired some of the best art in the past, and a musician showed that children's feeling for nature led them spontaneously to the same point of view that many great composers had immortalized in their creations. Another claimed that children were best studied not at rest or at work, but when most intensely and spontaneously active, as at recess and at play, and that out of door games were better than indoor ones for obeervation; thet school work often checks and stunts child hood because teachers have not stood in the very closest relation to children. The universal opinion was that all teachers could easily be trained to aid science by making certain classes of observations and that the making of the directed observations would fit them for an epplication of the results.

It was agreed that henceforth we must teach children rather than otadies. It was observed that the habit of rapid motion, of quick, mertal activity and mathematical power often went together. Dr. Christopher, basing his opinion on Ratchford's Neuroses of Children, stated that medical men are just beginning to really know about diseases of children and that it is hardly yet understood that diseases of the same kind differ in vearly every respect from what they are in adults.

Mr. Yoder advanced the opinion that biographies of great men are so unreliable on account of the misapprehension of childhood and in. sisted that they wonld continue to be fantastic until biographers learned to give due regard to the long period of growth.

A number of speakers urged that child study should always be a part of salvage work among the poor, and one man urged the study of character and temperament as a basis of treatment of the individual, which must be as profoundly different as men are. Dr. Hall gave three addresses at this congress on Aspects of Child Study from his standpoint, one or more of which will appear in full in the next volume of the Proceedings of the Society.

The selection of Col. Parker, as President of the Child Study Section of the N. E. A. for the next year and the appointment of Dr. Colin A. Scott, an expert from Clark University, to represent child study in the Chicago Normal School, the gradual affiliation of Dr. McMurray and other leading Herbartians with the movement, the surprising growth of Dr. Krohn's Child Study Monthly, Dr. Dewey's new model school, based largely upon child study, the fact that Drs. Thurber and McMurray are to co-operate with him at the University of Chicago in extend. ing the movement; the amazing interest and enthusiasm already aroused - these and many other influences combine to place this State still more in the van as the most active center of propaganda, and of the most efficient organization in the country.

New York. The work of Child Study in New York is largely done through the Department of Education. Such State adoption of Child Study is unique and gives more force to the annual reports than if they were admitted by courtesy. May the day be close at hand when every State report has its Department of Child Study as the Forty-Second one of New York, under the superintendence of Hon. Charles Skinner, has.

Mr. Charles H. Thurber at the close of his Hints on Child Study, Document No. I, unconsciously admits that even school teachers are 
but children of a larger growth, for he says that the names of teachers in the State who are helping in this work will be published as an honor list in the annual report. Mr. Thurber followed a study of Children's Fears and Superstitions by one of their Hopes. This latter paper makes a very interesting official document, and shows the age at which the various occupations appeal most strongly to childhood ; for instance, after nine, the number of boys who want to be soldiers rapidly increases; at twelve and thirteen the millinery business springs into great prominence with girls, etc. Superintendent Skiuner reviews this study in his report, summing up its value in the following terse way: This study of chiliren may result in bringing to teachers a more practical knowledge of psychology, and later on, when we have passed the ele. mentary stages of this work, there will doubtless come that which has undisputed scientific value. The Buffalo School of Pedagogy has a child study department, Miss Ida C. Bender being the instructor. A mother's club, known as the Highland Park Mother's Club, was organized in 1895 .

In Utica, Mr. George Griffith has issued blanks for teachers' study of children's emotions, reasoning, imagination, memory and attention. The Mother's Club of Buffalo contributes Suggestions for Study of Individual Children especially as to Formation of Habits, Fatigue, Keenness of Senses and Physical Characteristics. These suggestions are published in the Transactions of the Illinois Society for Child Study, Vol. 1, No. 4. The Teacher's College of New York has a well-detined course of child study, Miss Zebring, of the Collegiate Alumne, having a strong influence there, which she uses for the advancement of this study among teachers who are yet inclined even among college graduates to think the book more important than the child. Miss Anna $K$. Eggleston, who conducts Institutes throughout the State, has been studying the children two years and has the needs of country children so close to her heart that one feels as if she were a kind of Providence in that too neglected part of the school life of the world.

At the N. E. A. meeting in July, at Buffalo, the first session of the Child Study Section filled the largest church in town with an overfow meeting, where the papers were repeated. The next day the large Music Hall, seating four thousand people, was crowded except some seats in the back part of the gallery. A long and successful programme had beeu provided by President Earl Barnes, and at the close Professor Bryan, of Indiana, Professor Thurber, of Chicago University, and Professor Wolfe, of Nebraska, were appointed a committee to effect an interstate organization. The fact that State Superintendent Skinner is to be President at the next $N$. E. A. insures at last a man in that position who has not only heard of child study but thinks well of it. The section has grown in three years to be far larger than any other, and that without a sign of favor from the ultra conservative board of control of the N.E.A. It was allowed no place upon the programme of the geteral session and most of the conservative leaders, old and young, are on record against it. Indeed it has now come to represent the new as opposed to the old in education, and the difference between the $N$. E. A. machine and the large group of vigorous young men assembled at the close of the last section meeting to take counsel and form plans, represent in a clear cut way nearly all the issues at present pending in education between the conservative and progressive forces, and between the past and the future. The external organization of the $N$. $F$. A. has vastly improved within recent years but its internal quality lags strangely behind the present state of the most advanced pedagogy. old leaders with effete ideas are still allowed to take the time of the association to justify or modify the errors of their youth. The N. E. A. 
does not see that something far transcending the reports of the Conmittees of Ten and Fifteen is at the door and that it has now the greatest opportunity in its history to resoul itself by a new policy which instead of ignoring child study should adopt it by a large appropriation from its funds, to be placed without restriction in the hands of those who could best use it, with no conditions except that its results should be printed in the Proceedings. With such things as are now possible in the way of making education both more professional and more scientific, it seems to the writer nothing less than a shame to education and a sin against childhood to waste the time and deaden the interest of vast. audiences with the ponderous platitudes or polemics of educational laymen and pedagogic phrase makers. Nothing would lift the character of these great meetings like adopting the simple methods of scientific associations where the best places on the programme are given to those who have added most during the year to the sum of the world's knowledge in the field and those who have boomlets or represent geographical sections, official stations, friends of officers are rigidly excluded; merit, matter and quality being the sole considerations.

The new school of pedagogy at Buffalo, led by Professor McMurray, began immediately after the session of the N. E. A. a two week's summer school, modelled almost entirely on the plan of Clark University, Professor James representing psychology and Professor O'Shea child study.

Iowa. The last circular sent out by State Superintendent Sabin in Iowa shows that the Iowa Society for Child Study has followed its first outline of work and has made and proved the need of eye and ear tests for every child that enters the public schools. Superintendent Kratz has directed a study of the characteristics of the best teacher as recogvized by children, the report and results of which are published in the last number of the Pedagogical Seminary.

The sixth study is one of children's preferences. Superintendent Kratz seems a bit depressed by the wail of dissatisfaction from girls who universally hate dish-washing, and seems to think it bodes some ill for the future home, but I fancy further study will place this aversion to dish-washing among the things that girls suffer and outgrow, from generation to generation. When I suffered most from this bane of a girl's life my mother helped me over the difficulty by saying that all girls hated it for a time; she had hated it herself when she was a girl but grew to like it by doing it well and so would I. I perfectly remember my incredulity, but to look at it as a phase of girl life which would pass with the fashion of my dress was a direct help as it ought to be to any healthy minded girl. As we study the children I am sure we shall grow optimistic because they are so much more amenable and reasonable than we have thought them.

In the State University many tests, both physical and mental, have been made upon children between the ages of six and twenty-one years. The nature and results of these tests will be published as soon as they are cornpleted. Three hours a week are devoted to lectures on child study and related subjects. Extension lectures upon the subject have also been given by $G$. W. A. Patrick in various parts of the State.

Pennsylvania. The University of Pennsylvavia offers a course in Experimental Child Psychology. A Summer School of the University shows the usual time devoted to child study topics although Dr. Witmer does not allow the subject to be mentioned by any such dilletante and undignified term, and when we enter the Philadelphia University we must leave our modest Child Study outside and apply ourselves to Child Psychology. The prospectus of the work at this University indicates that much of the old psychology is included under the term 
of child psychology and that as jet we have little in the way of new results from this center.

Miss Mackenzie, Superintendent of Kindergartens in Philadelphia, has made returns on the Kindergarten Syllabus mentioned elsewhere.

Miss Marot reports a Mother Play class which makes an attempt to fit the games and songs of Frobel to the needs of the children as observed by mothers and kindergartners engaged in atudy of children, actually before or rather with them from day to day. Miss Marot went to Professor Royce a report of play with a pasteboard dog doll which it is hoped we may see. Miss Marot uses some of Mr. Barnes' questions, Pres. Hall's, Principal Rnssell's and her own. Mr. Allen, of the Institute for the Blind, is experimenting in physical paychology upon blind children in Philadelphia.

Superintendent Thomas Scott Lowden, of Greenville, has a valuable thesis on the First Half Year of an Infant's Life, which, as far as it goes, is perhape of more valne to Americans than Preyer's or Perez's notes because of the iafluence of heredity and different environment.

Kindergartners especially should familiarize themselves with this study because it is the record of a father who lived with his child several hours each day for six months; as be say 8 , from its first cry. This thesis touches upon movements, seeing, hesring, attention, emotions of joy, sorrow, anger and the will, as indicated in the first month.

New Jersey. In this State, Trenton Normal School and Miss Lillie $A$. Williams still make the center of work. Miss Williams may be quoted more profitably than reported. She writes me: "We have continued general observation following our modified form of Principal Russell's plan. Each pupil keeps a book in which she records her observations on children. By the end of the year each student has collected several hundred observations classified according to Principal Russell's blanks. $M y$ idea is to continue individual study during the school career of these children, thus in time having a life book of each, which ought to be of incalculable value to any teacher under whose instruction these children come. My pupils have made several tests for deafness, color blindness, and other eye defects, as well as work in testing power with other senses. Several child vocabularies have been collected and some investigations made concerning the time of day that pupils work best. Five thousand reports have been sent to President Hall upon his syllabi. I feel that the students have been led to intereat in and love of children, and have acquired a babit of observing them which will last through life, as well as formed an abiding interest in genetic paychology. I have spoken seven times in different parts of the State on Child Study, always to deeply interested auditors."

The Principal of the New Jersey State Normal School deserves the greatest credit for his steadfast patronage and support of Miss Wilfiams's work which has made this institution so widely and favorably known. This support on his part, if continued, will make the school historic as the source of by far the best as well as most copious data for the new genctic paychology.

Prof. J. Mark Baldwin, of Princeton, has issued a paper on Child Study Applied to Educetion, which is undoubtedly based upon his own studies, he having sent out a syllabus through the same medium which publishes his article, viz., The Illinois Handbook. His promised volume of Ivterpretations is still in the future.

Connecticut. It is a good omen that Miss Hunt is studying so-called dull children, and that even forty teachers out of seven hundred have responded to her appeal for such study. When we succeed in any city or State in getting the rights of the so-called dull children recognized 
by school boards, and proper appropriations for their instruction, we may cry with Simeon of old "now lettest thou thy servant depart in peace." The forty teachers who responded to Miss Hunt's appeal should have their names placed on a national scroll of honor. Professor Scripture has continued work along the lines indicated in my previous report. President Hall has lectured three times within the year at New Haven upon child study.

Michigan. Michigan has begun child study in a business-like way with the immediate sympathy and co-operation of the Superintendent of Pablic Instruction, who writes the introduction to the first Manual of Child Study sent out by the Department of Public Instruction of that State. Perhaps no organization for study of children 8080011 secured the help of the mothers of the children as this one in Michigan. The various syllabi used by the associstion are printed in the Michigan Manual of Child Study. Miss Marsh, of Detroit, has planned and organized a Mother's Club which meets at the schoolhouse to discuss discipline, diet, and every topic of importance to the well-being of the children, who must be better understood through these conferences. Her sister, a music teacher, has collected six thousand returns showing the kind of tunes Detroit children prefer. Superintendents Whitney and Hoyt have done good work during the year in popularizing the work both within and outside of the State. President Hall has lectured six times in various parts of the State during the past year.

Maine. At Farmington records have been kept of the work of the children, and many photographs taken, which accompany the reported observations. Reports on several of President Hall's syllabi have been handed Miss Swift, who says they have given her an insight into the natures of individuals never before understood and a revelation of pupils that could have been obtained in no other way. Mr. Small, of Clark University, has received thousands of returns from this center, which promises to rank next to New Jersey as a source of supply. Special credit is due to Mr. Purington, the local head of the work.

Indiara. Dr. Bryan, of the Indiana University, watches over the best interests of that State, and at the recent meeting of the N. $E$. A. made an able plea for the aniversities to resist the too popular demend for results that can be carried in a note book in the side pocket of such pseudo-psychologists as claim to be able to settle the affairs of the universe by an essay. Dr. Bryan was rather scathing in comparing some of the features of the educational meetings to a circus tent; his comments and sarcasm on some of the efforts that creep into print and public notice ticketed as child study were well timed, and it would be well if the cause could be saved from its friends by such an appeal, but it is likely to shake off incumbrances as time passes. Dr. Bryan attacked some of the syllabi that Child Study floats, saying that a good questionnaire is as hard to $w$ rite as a poem.

Of between three and four score of questionnaires collected at Worcester, besides those published there, scarcely half a dozen auggest anything new, and many are so vague, inane and impracticable as to be worse than worthless. If a movement is tested by the rubbish it floats, the vitality of child study is here most abundantly shown. A good questionnaire should open new, rich and distinct fine of work. It should aim to accomplish one definite thing, and its form should be such as to insure the casiest and most effective presentation of results.

Minnesota. Minnesota formed an Association for Child Study on December 31, 1895. Superintendent S. S. Parr was elected president. Immediate arrangements were made for co-operation of the teachers in the State through Round Tables. Mr. Galbreath, of the State Nor- 
mal School at Winona, took charge of this branch of the work, official reports of which may be found in the Child Study Monthly.

The Association has sent a comprehensive set of questions to graduates of the State Normal School, which will be of great service to those who attempt to make returns, and to the Society as well. The report from Winona of interesting discoveries is rather startling even to those of us who have long believed that much of the backwardness and indifference of children is attributable to physical causes and not to inental stupor.

To give direction in the study of children and in reading, a number of syllabi on the following topics were sent out: The Eyes of School Children and Their Defects; The Use of Stories; The Child, a Volume to be Read; Plan and Method in the Study of Children; A Study of Children's Readings; Unnoticed Educative Influences; Movements of Children; A Study of Memory; Unexpected and Incorrect Answers of Children; Unexpected and Irrelevant Questions of Children. Besides the many numerous and important references in the syllabi, the executive committee, to aid and encourage reading, has sent out a brief but very carefully selected bibliography on child study.

Professor Galbreath says in closing one of his papers on Child Study: For stupidity and stubbornness so frequently on the teachers' lips, we often need to substitute poor hearing or partial deafness and defective eye sight. 'This confession, let us remember, is a direct result of study of the pupils by the teachers.

E. A. Kirpatrick has issued a set of papers which he calls Suggestions for Observation; to be used by teachers in the Model Schools. Professor Kirk patrick has also given us a new tcxt book on Inductive Psychology which is an outgrowth of child study as all future psychologies must be in great measure.

L. H. Galbreath has formulated a course of study in eight parts, sent to teachers and others as Communication I, II, etc. Number II makes a study of my Place of the Story in Farly Education, giving a list of books for collateral reading. IV is a Plan and Method in the Study of Children. $V$ is a further consideration of Physical Phenomena, $R y t h$ mic, Sense and Finger Songs as treated in my book before referred to, and VI is upon Reading, Spelling, Observation and Arithmetic. This involves a study of eye and ear mindedness. VII is A Study of the Unexpected and Incorrect Answers of Children. VIII is A Study of Unexpected and Irrelevant Questions of Children.

Ove unique feature of this association is its syllabus, which puts the teacher under examination. She is asked a number of pertinent questions: What interested you in the study of children? how has your teaching been affected by the new movement? do you believe in it? etc.

Missouri. Missouri is almost the only large northern State which, so far as is known, does nothing in child study except at Kansas City. President Hall has given three lectures at St. Louis on the subject during the year. The great High School there has three teachers of a philosophy of mind which he pronounces the most diluted of all the inany extracts of Hegelism. The old formula are gone over in a way to inoculate the nind most effectively against the entrance of every trace of child study or empirical psychology. He knows no great educational center so dead to all the new philosophical interests that are so rapidly transforming the conceptions of the mind and its proper development as St. Louis, from the kindergarten to the university. This great city seems, with some individual exceptions, as dead and mechanized as it is self-complaisant, and is in the greatest need of an educational awakening.

Wisconsin. In Wisconsin all the work reported is based upon a 
syllabus issued by Mr. James Morse, of the University of Wisconsin. This syllabus covers a number of studies in the moral development of children and the relation of the child to authority.

South Carolina. A few of the most earnest meinbers of the original association for Child Study have organized a smaller club. Supt. Hamby has been making miscellaneous studies, particular attention being given to abuormal and defective children. This Association has an opportunity it should not neglect - that of studying the clay eating and snuff dipping children in isolated rural districts.

Colorado. Colorado has a Child Study section connected with its State Teachers' Association which has issued a syllabus fo: testing the conditions of mathematical work. The hints on the first page of their first syllabus should be incorporated in the Ten Commandments, so much needed at this stage of our Exodus from the pedagogical Eygpt.

Give your pupils no preliminary drill for these tests. Omit no test, "because your pupils have had no such work." Ability to do many things of tert develops without the teacher's aid. It will be no refection on you if your pupils make many failures. Poor papers have of ten to the expert as great value as the better ones; and the absence of the poor oncs may lead to wrong conclusions. Keep from them the fact that any special use will be made of their papers.

Ohio. Dr. Aikins, of Cleveland, has been making ethical studies in the public schools, and although his returns are not yet fully worked up he draws the conclusion that, except with a few of the youngest children, the Ten Commandments have no place in their ethical life, and that as children advance in years the morals of obedience and conventional observances give place to ideals of active self-assertion for humanity. Sympatuy and kinduess come much earlier than retribution and justice. These early conclusions and sweeping deductions are part of the dangers that beset every student, especially in the domain of ethics. If men like Sir Francis Galton fail to apply rigid scientific metlods in their ethical investigations, surely we should hold farreacling conclusions like this about the Ten Commandments in abeyance until we have more data to work upon. We need to remember that the souls of children are in that divine flux of which Heraclitus writes, and we are perhaps more in danger of misapprehension of the deepest things in children's lives than in the characters of adults.

Rhode Island. Mr. Gilman C. Fisher sends the following: The Rarvard Club School of Child Study has issued four syllabi and has organized seventeen Round Tables in different parts of the State, as follows: Six in Providence, five in Pawtucket, three in Cranston, one in Central Falls, one in Westerly, one in Cumberlend, with a total membership of 216. The Prwtucket Round Tables have also formed a Union Association, with honorary members. The Barnard Club Syllabi are models in point of neatness for filing and reference. Many syllabi are restricted in their general value by the errors of omission as to name of any person or even place, so that once separated from the letter of the sender they are almost useless to the historian, and are deprived of the official value they would otherwise have.

Nebraska. The North Western Journal of Educatiou has a department of child study, conducted by $G$. W. A. Luckey, of the University of Nebraska. This journal is edited by $\mathrm{J}$. $\mathrm{H}$. Miller and published in Lincoln. The July number is deroted to child study, the editing of this number being given entirely to Dr. H. K. Wolfe. Prof. Luckey has published in the American Journal of Psychology, Vol. VI, No. 4, an article on Comparative Observations of the Indirect Color Range of Children, Adults and Adults Trained in Color. This article was intended only as preliminary to a series for which Mr. 
Luckey has already collected data, but has had no time to put the papers in form for the benefit of his fellow-students.

The Nebraska Society for Child Study was organized January I, 1896 , with a membership of 74 , and in less than six months numbered 112. The Society justly prides itself on the fact that 100 teachers in Nebraska are subscribers to the Illinois Child Study Monthly. The University of Nebraska held a Summer School in June, 1896 , with a department of pedagogy, the first course of which was devoted to child study, and is directing study of fears, anger, etc., by the four methods of Russell, Hall, Barnes and Scripture, but original work is not begun until the second year.

Oregon. In Oregon, Professor M. G. Royal reports that Miss Agnes Stowell, of the Eastern State Normal, has been studying individual children by methods suggested by Stanford University. A new Educational Club, under the auspices of the State University, is about to publish a new journal, with a special department and editor for child study.

Alabama. In Alabama, Birmingham and Mobile report some work in observing and recording, and at the last State Association three papers were presented, one by Mrs. Cunningham on Tests in Arithmetic, carried through several grades and dealing with large numbers of papils, and bringing out the imitative, analytic and reasoning powers of children. Mr. Gilbert, of Florence, described ten cases of discipline and their poychological motives. Professor Van Wie described observations made by his own pupil teachers. He seeks to make studies both of classes and individuals, and although he thinks his own work desultory, regards it as most salutary for those making it.

Had it seemed wise to extend my survey outside this country, very interesting paragraphs conld be added about the progress of the work from the four chief British centers-London, Dublin, Cheltenham and Glasgow, where societies were organized more than a year ago by British students at the Clark Summer School. Child study is now represented at teachers' meetings, and at the Summer School at Cambridge University and elsewhere; Miss Mary Louch has sent in a valuable article on Children's Interests and Aims. A few returns of exceptional value have been received at Clark University from France and Germany, and others from Australia, Japan, South Africa, China, South America, North Africa and elsewhere. Another year it would be desirable to have these included in a general survey.

If the movement stopped to-day one result is already secure. Teachers have grown more interested in individual pupils, understand them better and sympathize with them more. Parents have acquired deeper reverence and greater love for childhood. In place of the old-time child literature expressing parental sentiment toward childhood, the ideal of a new and very different juvenile literature which is sure to make the old seem conventional, artificial and unnatural, is being developed. That periodical, religious and other juvenile literature, is in need of regeneration, is already apparent. If one of the chief tests of a civilization is the way in which it regards and treats childhood, ever so little change in this all-important regard, although it may be too vast for the average teacher or parent to even glimpse it, is of incalculable beneficence. This result, I think, is the largest of all possible products of the movement, and may be said to be already secured. It has changed the methods and standpoint of thousands who have made no returns whatever, and of thousands more who have jotted down notes which are of no scientific importance. Again, it has already been triumphantly shown that any intelligent parent or tcacher may jot down facts about dolls, fears, anger, or answer ques- 
tions about moon, folk lore, fads, etc., which are of the utmost value for science. Some psychological facts are almost as concrete as fossils, which are the same, whether picked up by a man of science or by a peasant. While plenty of points need expert treatment, it is a feature of all anthropological work that the common observer and the apecialist can 00 -operate.

Perhaps the result of child study that appeals most directly to the popular mind is in the direction of the physical wrongs done children with defective eyes and ears. Henceforth it is agreed that the seating of school children shall conform to their needs in this regard; methods of teaching reading and writing must be and already are modified in some schools. Less suppression of spontaneous movements is practiced since child study has proven that such movements are necessary to every normal child. The abandonment of fine work in kindergartens is due to study of the children as affected by the work. Conditions of fatigue are better understood and study hours arranged with reference to the child's best study time. Drawing will have a larger amount of time given to it in the first years of school life, in accordance with the newly-discovered interest of children in it as a means of expression, not in any as yet organized school of drawing, but something based on the children's interests and abilities. Child study has called attention to the individual child as nothing else could have done, and has put an effectual dam in the way of much of the old-time mass teaching. The new relation between parent and teacher, which matual study of the children has brought about, is one of the most hopeful results of this work. Most important of all, perhaps, is the new life which every teacher testifies she has received from the more natural and sympathetic relation which child study immediately establishes wherever it is undertaken. And it is the teacher who receives, and will continue to receive, the first fruits of these studies, for there is nothing in all the world so mysterious, so beautiful and inspiring, so refreshing to the deepest instincts of our complex natures, as direct personal contact with the little children.

Norf.-The writer intends to continue these annual reports and begs all readers to send to her address, West Roxbury, Mass., any printed or written matter stating what they or their acquaintances do during the academic year $1896-7$. 